\title{
Influence of crosslinking agent on the effectiveness of flame retardant treatment for cotton fabric
}

\author{
DOI: $10.35530 / 1 T .070 .05 .1610$
}

\section{ABSTRACT - REZUMAT}

\section{Influence of crosslinking agent on the effectiveness of flame retardant treatment for cotton fabric}

In this study, the commercial organophosphorus compound Pyrovatex CP New was used as a flame retardant for cotton fabric. Citric acid and a modified dihydroxy ethylene urea (DHEU) labelled Knittex FFRC were used as crosslinking to increase the flame-retardant laundering durability of treated cotton fabric. There have been some studies showing that Chitosan has the potential to improve flame retardancy and laundering durability of flame retardant treated cotton fabric. Thus, Chitosan, which has the molecular weight of 2.600 (water soluble) and the deacetylation degree of approximately $75 \%$, is added to finishing solution for flame retardant treatment of cotton fabric. The padding-drying-curing method was used in this study. After treatment, all samples were examined to determine the chemical absorption level. The $45^{\circ}$ flammability test characteristics and LOI value of untreated and treated samples after different number of washing cycle were determined to assess the flame retardancy of the treated fabric and its laundering durability. In addition, to assess the impact of this treatment on the mechanical strength and ecology of the fabric, the tensile strength and free formaldehyde content of the treated fabric were also evaluated.

Keywords: flame retardant, crosslinking agent, cotton fabric, Pyrovatex CP New

Influența agentului de reticulare asupra eficienței tratamentului de ignifugare pentru țesătura din bumbac

În acest studiu, compusul comercial de organofosfor Pyrovatex CP New a fost utilizat ca agent de ignifugare pentru țesăturile din bumbac. Acidul citric și dihidroxietilen ureea modificată (DHEU) etichetată Knittex FFRC au fost utilizaţi ca agenți de reticulare, pentru a crește rezistenţa la spălare a țesăturii de bumbac tratată cu agent de ignifugare. Există studii care arată că chitosanul are potențialul de a îmbunătăți rezistența la flacără și durabilitatea spălării țesăturii de bumbac tratate ignifug. Astfel, chitosanul, care are greutatea moleculară de 2,600 (solubil în apă) și gradul de deacetilare de aproximativ $75 \%$, se adaugă soluției de finisare pentru tratamentul ignifug al țesăturii de bumbac. Metoda de fulardare-uscare-reticulare a fost utilizată în acest studiu. După tratament, toate probele au fost examinate pentru a determina nivelul de absorbție chimică. Caracteristicile testului de inflamabilitate la $45^{\circ}$ și valoarea LOI a probelor netratate și tratate, după un număr diferit de cicluri de spălare au fost determinate pentru a evalua rezistența la flacără a țesăturii tratate și durabilitatea acesteia la spălare. În plus, pentru a evalua impactul acestui tratament asupra rezistenței mecanice și a caracteristicilor ecologice ale țesăturii, a fost de asemenea evaluată rezistența la tracțiune și conținutul de formaldehidă din țesătura tratată.

Cuvinte-cheie: agent de ignifugare, agent de reticulare, țesătură din bumbac, Pyrovatex CP New

\section{INTRODUCTION}

Cotton fabric is an important textile widely used to produce apparels, home furnishings, and various industrial products due to its characteristics of softness, breathability, and moisture absorbability [1]. However, the vital drawback of cotton fabric, i.e., flammability, limits its use. It ignites easily and is frequently implicated in fire. Cotton cellulose undergoes degradation on ignition, forming highly combustible volatile compounds mainly laevoglucose with the propagation of fire causing injuries and fatalities in fire accidents [1].

Flame retardant fabrics are needed for a variety of uses such as home furnishing and decorations (curtains, drapes, upholstery, bedding, mattresses, wall coverings and trimmings etc.); uniforms for fire-fighters; apparels and garments (sleepwear, nightwear, children's wear, loose garments, sarees, shawls, kitchen wear, etc., where there are chances of accidental contact with flame) etc. [2].

Flame retardants are applied to textiles to make them noninflammable or self-extinguishing [3]. Flame retardants with chemical and/or physical action retard or block the process of burning in particular phases of burning so that they stop the inflow of heat to the polymer, block the access of oxygen, increase the generation of non-flammable gases and the content of char residue; or reduce the generation of flammable ones, acting in the gaseous and condensed phases. These mechanisms often cannot be clearly separated [4].

Many studies have attempted to impart flame retardancy in cotton by grafting flame retardant (FR) groups, coating with flame retardant layers, or directly adding fire retardants to polymer materials [5]. The most common classes of flame retardants are brominated, phosphorus, nitrogen, chlorinated, and 
inorganic [3]. Halogen-containing FR systems have come under scrutiny due to health and environmental concerns and have recently been restricted in many communities. Recent developments of FR molecules have focused on organophosphorus compounds [6]. Phosphorus-based FR has become a popular alternative to halogen compounds because of their environmentally friendly by-products and their low toxicity. Also, their low production of smoke in fire furthers their appeal. It is a highly effective flame retardant for cellulose and cellulose derivatives. These compounds promote dehydration and char formation [7]. One of the most commercially successful agents is $\mathrm{N}$-methylol dimethylphosphonpropionamide, known under the trade name of Pyrovatex CP New (PR). Some studies have shown the effect of PR on flame retardancy for cotton fabrics [8-12].

One important task is to create a covalent bond between the PR and the fabric to ensure the durable flame-retardant cotton fabric. In studies [8, 11], the flame retardant laundering durability of cotton fabrics treated with PR agents can be improved by resin application. Organophosphorus agents are combined with melamine resins and an acid as catalyst such as phosphorus acid. The purpose of the melamine resin is to provide nitrogen in order to enhance the flame retarding performance of the treated fabric through synergism with phosphorus [8]. However, it shows the drawback of high formaldehyde release when used with methylated melamine based crosslinking, a known carcinogenic compound [9]. Another drawback is the significant mechanical strength loss of the treated fabric due to curing at a high temperature and in the highly acidic condition of $\mathrm{pH} 1-2$ with the presence of phosphoric acid [11].

For this reason, some studies [8-10], tried to use polycarboxylic acids instead of melamine resin particularly, the 1,2,3,4-butane tetracarboxylic acid (BTCA) and citric acid (CA) have attracted significant research interest as formaldehyde-free finishing agents. These acids can form an ester cross-link structure with cellulose. By forming two or more ester bonds with cellulose macromolecules, these can produce a crosslinking fiber structure possessing a high level of crease recovery $[9,13]$. However, BTCA has 4 carboxyl groups and CA has 3 carboxyl groups, if another $-\mathrm{COOH}$ group of them can form an ester bond with $\mathrm{PR}$, it would produce a cross linkage between cellulose and PR. Carboxylic acids can esterify cotton fibers in the presence of sodium hypophosphite as a catalyst [13]. However, there was also the mechanical strength loss of treated fabric, that was due to the high temperatures and high acidic condition of curing although this loss was less than the use of phosphoric acid [10].

For the aforementioned reasons, DHEU (dihydroxy ethylene urea) and its modified compounds are used as crosslinking agent in finishing for cotton. With DHEU, PR can react with cellulosic substances by crosslinking with ether bonds. In comparison with the polycarboxylic acids, DHEU has only two hydroxyl groups to make cross linkage between hydroxyl groups of the cellulose and PR, while BTCA has four carboxylic groups and CA has three groups to make cross linkage between PR and cellulose. Thus, in principle, the cross linkage between cellulose and PR is easier to form with CA or BTCA than with DHEU. However, the mechanical strength of cotton fabric can be reduced in the esterification reaction. Recently, based on DHEU, Huntsman has introduced a new crosslinking labelled Knittex FFRC that can make cross linkages to cellulose without the help of the catalyst. It was used as crosslinking in softening and antifungal finishing of cotton fabric [14-15]. These studies show that Knittex FFRC was a good cross-linker between cotton and finishing agents. Could it be used as cross-linker between cotton and PR? The overall efficiency of the Knittex FFRC and CA should be evaluated according to the flame-retardant laundering durability as well as the mechanical strength loss of the treated fabric.

In order to clarify this issue, in this study, cotton fabric was treated to be flame retardant by $P R$ and two crosslinking options: citric acid and Knittex FFRC. The objective of the work is to select the most effective crosslinking by creating a durable bond between cellulose and PR. Furthermore, it had less effect on mechanical strength as well as on the ecological properties of the fabric. In addition to the above two experiments, a third experiment was carried out in which CA was used as crosslinking and Chitosan was added into the finishing solution with the aim to increase the flame retardant efficiency of the fabric. Chitosan (CTS) is an amino polysaccharide obtained by the alkaline deacetylation process of chitin, a naturally occurring polymeric material. In this study, CTS acts as a natural nitrogen source that synergizes with phosphorus to increase the fire efficiency $[16,17]$. Finally, the ecological, physical, and thermal properties of treated cotton fabrics were investigated to choose the most effective crosslinking.

\section{EXPERIMENTAL}

\section{Materials}

The $100 \%$ cotton fabric was supplied by Hanoi Dyeing Joint Stock Company, Viet Nam. The fabrics were desized, scoured, bleached and mercerized. Their technical characteristics are showed in table 1.

Table 1

TECHNICAL CHARACTERISTICS OF THE FABRIC

\begin{tabular}{|c|c|c|c|c|c|}
\hline \multirow{2}{*}{$\begin{array}{c}\text { Construc- } \\
\text { tion }\end{array}$} & \multicolumn{2}{|c|}{$\begin{array}{c}\text { Linear } \\
\text { density of } \\
\text { yarn (tex) }\end{array}$} & \multicolumn{2}{|c|}{$\begin{array}{c}\text { Fabric } \\
\text { density } \\
\text { (yarn/10 } \mathbf{~ c m} \text { ) }\end{array}$} & \begin{tabular}{c} 
Surface \\
mass of \\
fabric \\
\cline { 2 - 5 }
\end{tabular} \\
\cline { 2 - 5 } & warp & weft & warp & weft & wart \\
\hline $\begin{array}{c}\text { Twill } \\
\text { weaves 2/1 }\end{array}$ & 17.24 & 35.71 & 560 & 230 & 190 \\
\hline
\end{tabular}

Pyrovatex CP New (PR), Knittex FFRC (K), Invadine PBN were supplied by Huntsman. Pyrovatex CP New (PR) is a $\mathrm{N}$-methylol dimethylphosphonpropionamide, 
in this study, it was used as flame retardant agent. Knittex FFRC is a modified dihydroxy ethylene urea, it was used as crosslinking and Invadine PBN as tenside agents.

Citric Acid (CA) was used as another crosslinking to compare the effect on flame retardant laundering durability to Knittex FFRC agent. Sodium hypophosphite (SHP) was used as catalyst for the case of crosslinking agent CA, which was supplied by Xilong Scientific.

Chitosan 187.000 Da, with the deacetylation degrees of about $75 \%$ was purchased from the Chitosan Vietnam One member Limited Company. This Chitosan was irradiated at Department of Radiation Technology, Hanoi Irradiation Center in order to have chitosan with MW 2.600 (water soluble) and $\mathrm{DD} \approx 75 \%$.

The chemical formulas of the main agents are showed in table 2.

Table 2

CHEMICAL FORMULAS OF THE MAIN AGENTS

\begin{tabular}{|c|c|}
\hline Agent & Chemical formula \\
\hline Pyrovatex CP New & 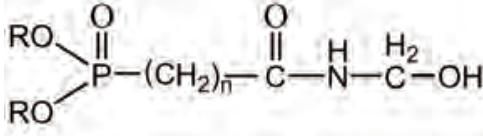 \\
\hline Citric Acid & $\mathrm{OH}-\left.\right|_{\mathrm{CH}_{2}-\mathrm{COOH}} ^{\mathrm{C}}-\mathrm{COOH}$ \\
\hline Chitosan & $\mathrm{HO}-\mathrm{CH}_{2}-\mathrm{R}_{1}-\mathrm{NH}_{2}$ \\
\hline $\begin{array}{l}\text { Dihydroxy ethylene } \\
\text { urea }\end{array}$ & $\mathrm{HO}_{\mathrm{H}}^{\mathrm{I}} \stackrel{\mathrm{H}_{\mathrm{H}}^{\mathrm{O}}}{\mathrm{C}}-\mathrm{OH}$ \\
\hline
\end{tabular}

\section{Method}

\section{Flame retardant treatment for cotton fabric}

One bath, pad-dry-cure technique was used in this study for flame retardant treatment. First, the fabric was impregnated in finishing solution, then padded, dried and cured.

Finishing solution formulations:

The three aforementioned formulations were used in this study, they were named as FS1, FS2, FS3. The details of these formulations are presented in table 3 Flame retardant treatment process:

All three experiments were carried out under the same conditions: The fabric samples $35 \times 35 \mathrm{~cm}$ were impregnated with finishing solution (the bath formulations are shown in table 3 ), then padded with a wet pick-up of approximately $80 \%$ by padder SDL D394A. The padded samples were dried at $110^{\circ} \mathrm{C}$ for $5 \mathrm{~min}$ utes. After that these samples were cured at $180^{\circ} \mathrm{C}$ for 2 minutes. The Stenter SDL D398 was used for

\begin{tabular}{|c|c|c|c|c|c|c|}
\hline \multicolumn{7}{|c|}{ FINISHING SOLUTION FORMULATIONS } \\
\hline $\begin{array}{c}\text { The } \\
\text { bath }\end{array}$ & $\begin{array}{c}\text { PR } \\
(\%)\end{array}$ & $\begin{array}{c}\text { K } \\
(\%)\end{array}$ & $\begin{array}{c}\text { CA } \\
(\%)\end{array}$ & $\begin{array}{c}\text { SHP } \\
(\%)\end{array}$ & $\begin{array}{c}\text { Tenside } \\
(\%)\end{array}$ & $\begin{array}{c}\text { CTS } \\
(\%)\end{array}$ \\
\hline FS1 & 40 & - & 7 & 6.5 & 0.5 & - \\
\hline FS2 & 40 & - & 7 & 6.5 & 0.5 & 1 \\
\hline FS3 & 40 & 7 & - & - & 0.5 & - \\
\hline
\end{tabular}

*\% weight of fabric

drying and curing steps. Next, the samples were washed under running water for 5 minutes and then dried in the stenter at $110^{\circ} \mathrm{C}$ for 3 minutes. The treated samples were stored in the polyethylene bags and in the standard laboratory conditions for 24 hours before any further analysis.

\section{Treated samples washing}

To determine the flame retardant durability of the fabric after treatment, the treated samples were washed in accordance with ISO-6330 standard clause 6A [19] but without added detergent. The Electrolux EW $1290 \mathrm{~W}$ front load washing machine was used. Washed samples were stored after 5, 10, 15, 20 and 30 wash cycles to test the flammability of samples.

\section{Assessment of treated fabric's properties}

Determination of real uptake of recipe chemicals (add-on\%) on fabric

The real uptake of recipe chemicals (add-on\%) on the fabric after the aforementioned treatment was calculated using Eq. (1) and the results are presented in table 4.

$$
\text { Add-on }(\%)=\frac{W_{F}-W_{0}}{W_{0}} \times 100
$$

In Eq. (1), $W_{F}$ is the standard condition weight of the treated sample, and $W_{0}-$ the standard condition weight of the untreated sample.

The test was repeated six times for each finishing solution. The final result is an average of the 6 tests Flammability test

The $45^{\circ}$ flammability test method (ASTM D 1230 94) [20] was used for evaluating the flammability of the untreated and finished fabrics. The test was carried out at Chemical textile LAB of Hanoi University of Science and Technology.

LOI (limiting oxygen index) test

The LOI values of the control and finished cotton fabrics were measured in accordance with the ASTM D 2863-97 standard method [21] at Laboratory of Polymer Center of Hanoi University of Science and Technology (HUST).

Tensile strength test

Tensile strength of the fabric was determined according to ISO 13934-1:2013 standard method [22] at Testing Center of Textile - Leather Materials of HUST Formaldehyde content measurement

The free formaldehyde content of FR finished specimens was tested with reference to the guidelines 
given in EN ISO 14184-1:1998 standard [23] at zero wash and after 01 washing cycle at Chemical textile LAB of HUST.

\section{RESULTS AND DISCUSSION}

Reaction mechanisms of the chemical agents

In the first experiment (FS1): in this experiment, the effective ester crosslinking by CA between PR and cellulose illustrated by a reaction mechanism given in Scheme 1. However, the ester crosslinking by CA could be also produced between two cellulosic molecules, which could enhance crease recovery of fabric. Besides, it could be also created between two PR molecules, because of not linked to cellulose so it could be removed in washing.

In the second experiment (FS2), there are many cases that could be happened. The ester crosslinking by CA may be between PR and cellulose (Scheme 1).
CA also could react with chitosan by esterification reaction (with $\mathrm{OH}$ group of chitosan) or by amidation reaction (with amine group of chitosan). Thus, the crosslinking by CA could be produced between PR and chitosan, also between chitosan and cellulose and so on.

In the third experiment (FS3): the effective ether crosslinking by DHEU between $\mathrm{PR}$ and cellulose illustrated by a reaction mechanism is given in case 1 of Scheme 2. Besides, DHEU may be reacted only with cellulose (case 2 ) or only with PR (case 3 ).

\section{The FR uptake of finished fabric}

The real uptake of recipe chemicals (add-on\%) on the fabrics treated with three finishing solutions are presented in table 4.

The chemicals add-on $\%$ on the sample treated with FS3 (using Knittex FFRC) is only $10.7 \%$ while it is

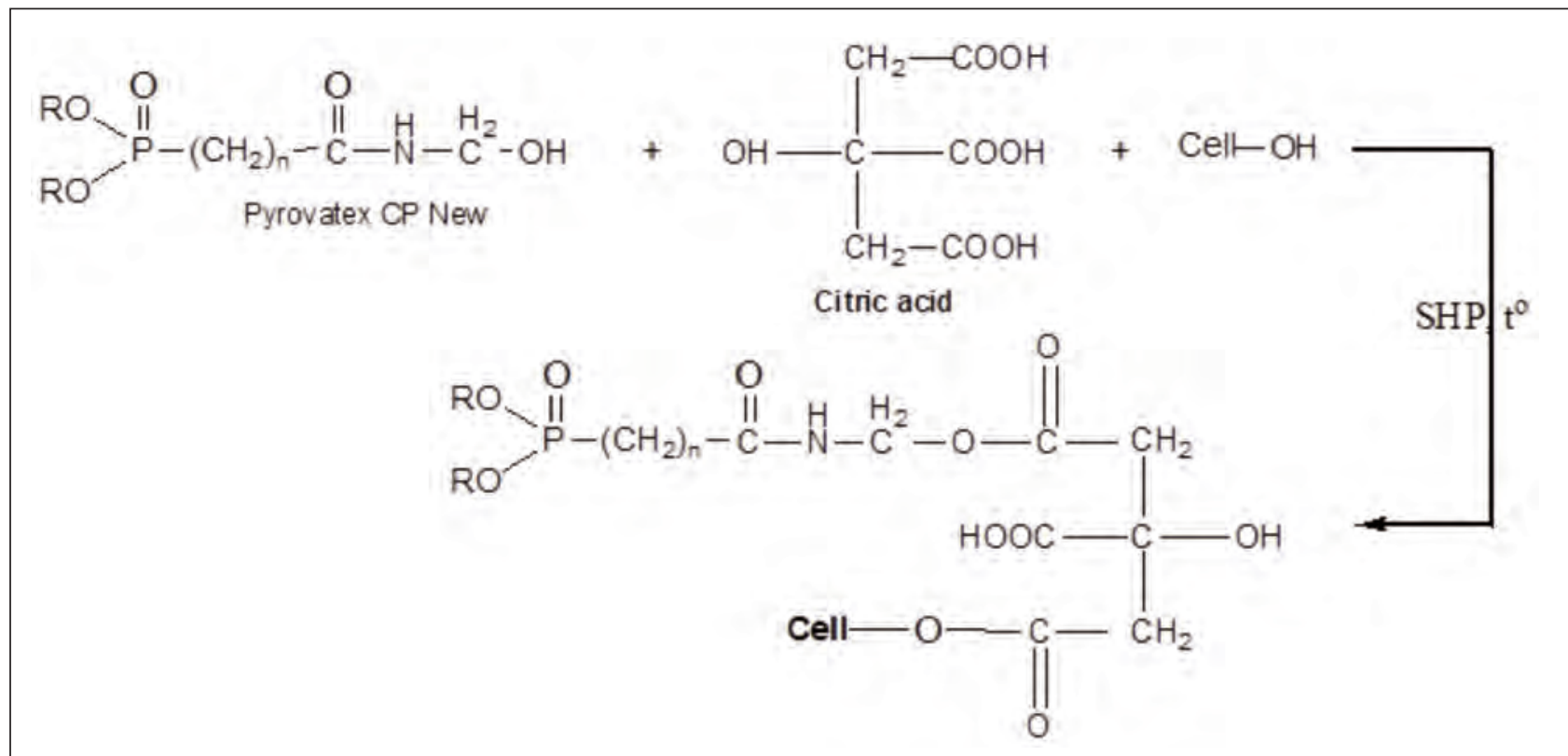

Scheme 1: Crosslinking mechanism of CA with Pyrovatex CP New and cellulose [10]

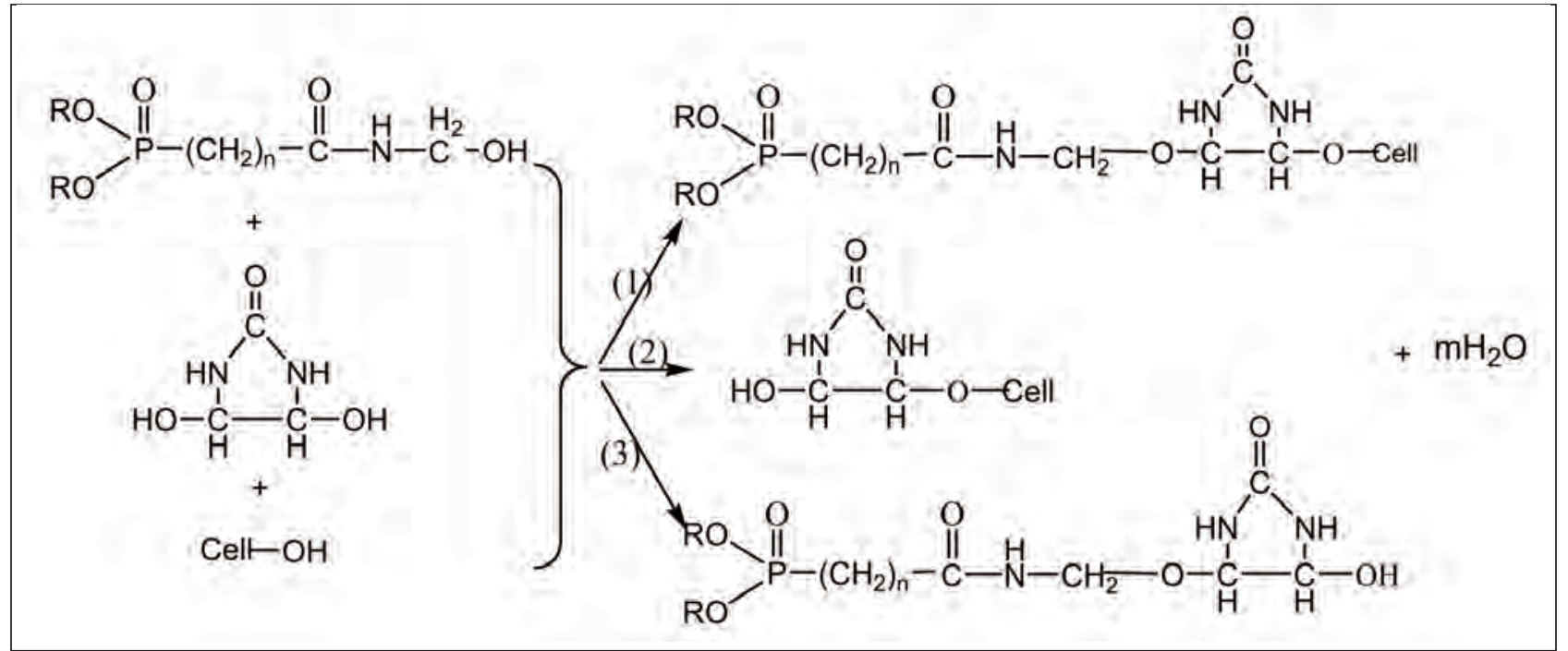

Scheme 2: Crosslinking mechanism of DHEU with Pyrovatex CP New and cellulose [18] 
Table 4

THE REAL FR UPTAKE (ADD-ON\%) ON TREATED FABRICS

\begin{tabular}{|c|c|c|c|}
\hline \multirow{2}{*}{$\begin{array}{c}\mathbf{N}^{\circ} \text { of test } \\
\text { for each FS }\end{array}$} & \multicolumn{3}{|c|}{ Add-on of treated sample (\%) } \\
\cline { 2 - 4 } & FS1 & FS2 & FS3 \\
\hline 1 & 17.35 & 19.08 & 10.19 \\
\hline 2 & 17.90 & 15.55 & 9.86 \\
\hline 3 & 17.81 & 18.64 & 11.94 \\
\hline 4 & 18.53 & 18.00 & 11.06 \\
\hline 5 & 17.54 & 18.01 & 10.93 \\
\hline 6 & 17.68 & 14.43 & 10.07 \\
\hline Average of Add-on (\%) & 17.80 & 17.28 & 10.67 \\
\hline Standard deviation & 0.18 & 0.38 & 0.26 \\
\hline
\end{tabular}

$17.8 \%$ and $17.28 \%$ for FS1 and FS2 respectively, indicating the excellent bonding between PR and cellulose structure in the presence of CA crosslinking. This phenomenon might occur because CA has 3 $\mathrm{COOH}$ groups for linkage while Knittex FFRC (DHEU) has only $2-\mathrm{OH}$ groups as said on. However, the add-on decreases $0.52 \%$ for FS2 in comparison with FS1. It is possible that the addition of chitosan into the solution without any supplement of CA is the cause of this phenomenon. Could this amount of add-on be beneficial to the flammability behavior of treated fabrics? This will be clarified in the test of flammability of fabrics.

\section{Effect of crosslinking on the flammability of the finished fabric}

To evaluate the flame retardant properties of the treated and laundered fabrics, $45^{\circ}$ flammability characteristics of the samples were investigated. The results of these tests are presented in table 5 and figure 1.

Table 5 and figure 1 show that the control sample burned vigorously after direct exposure to the ignition source. The ignition time was only 3 seconds. After removing the combustion source, the sample continued to burn until it had burned out. The cotton fabric almost completely burned out without any remains (figure 1,a). Furthermore, there was 9 seconds of afterglow. In contrast to the untreated sample, all treated samples and treated samples after different washing cycles showed good behaviors against the $45^{\circ}$ flammability test: the ignition times were 9 seconds. After removing the combustion source, the samples were extinguished immediately. The afterflame times and afterafterglow times were always zero.

The observations on table 5 and figure $1, b, c, d$ show that there were char formations in the sample areas exposed to the flame. This phenomenon of treated samples may be due to the phosphorus flame retardant agent, which promoted the dehydration of the cotton fabric when the fabric was thermally decomposed [5]. However, the differences in char lengths of the samples were also observed. There was virtually no difference in the char length of the samples treated with 3 different finishing solutions for up to 15 wash cycles. But from 20 washing cycles on, the treated sample with FS3 had much shorter char length than the other two (better flame retardant). Comparing the results of table 5 with the results of table 4 , it is apparent that the $45^{\circ}$ flammability behaviors of treated fabrics were not corresponding to their FR add-on. In order to better understand this phenomenon, the LOI of treated fabrics was investigated.

Table 5

$45^{\circ}$ FLAMMABILITY CHARACTERISTICS

OF CONTROL, TREATED SAMPLES AFTER 0, 5, 10, 15, 20, 30 WASH CYCLES

\begin{tabular}{|c|c|c|c|c|c|}
\hline Sample & $\begin{array}{l}\text { Number } \\
\text { of wash } \\
\text { cycles }\end{array}$ & $\begin{array}{c}\text { Ignition } \\
\text { times } \\
\text { (s) }\end{array}$ & $\begin{array}{c}\text { After } \\
\text { flame } \\
\text { times } \\
\text { (s) }\end{array}$ & $\begin{array}{c}\text { After } \\
\text { glow } \\
\text { times } \\
\text { (s) }\end{array}$ & $\begin{array}{l}\text { Char } \\
\text { length } \\
(\mathrm{mm})\end{array}$ \\
\hline Control & - & 3 & 36 & 9 & $\begin{array}{l}\text { Compl- } \\
\text { etely } \\
\text { burned }\end{array}$ \\
\hline FS1 & \multirow{3}{*}{0} & 9 & 0 & 0 & $20 \pm 1$ \\
\hline FS2 & & 9 & 0 & 0 & $22 \pm 2$ \\
\hline FS3 & & 9 & 0 & 0 & $22 \pm 2$ \\
\hline FS1 & \multirow{3}{*}{5} & 9 & 0 & 0 & $25 \pm 3$ \\
\hline FS2 & & 9 & 0 & 0 & $23 \pm 2$ \\
\hline FS3 & & 9 & 0 & 0 & $26 \pm 2$ \\
\hline FS1 & \multirow{3}{*}{10} & 9 & 0 & 0 & $25 \pm 2$ \\
\hline FS2 & & 9 & 0 & 0 & $25 \pm 2$ \\
\hline FS3 & & 9 & 0 & 0 & $26 \pm 3$ \\
\hline FS1 & \multirow{3}{*}{15} & 9 & 0 & 0 & $26 \pm 2$ \\
\hline FS2 & & 9 & 0 & 0 & $25 \pm 1$ \\
\hline FS3 & & 9 & 0 & 0 & $27 \pm 3$ \\
\hline FS1 & \multirow{3}{*}{20} & 9 & 0 & 0 & $31 \pm 4$ \\
\hline FS2 & & 9 & 0 & 0 & $30 \pm 3$ \\
\hline FS3 & & 9 & 0 & 0 & $27 \pm 2$ \\
\hline FS1 & \multirow{3}{*}{30} & 9 & 0 & 0 & $39 \pm 4$ \\
\hline FS2 & & 9 & 0 & 0 & $41 \pm 3$ \\
\hline FS3 & & 9 & 0 & 0 & $27 \pm 2$ \\
\hline
\end{tabular}

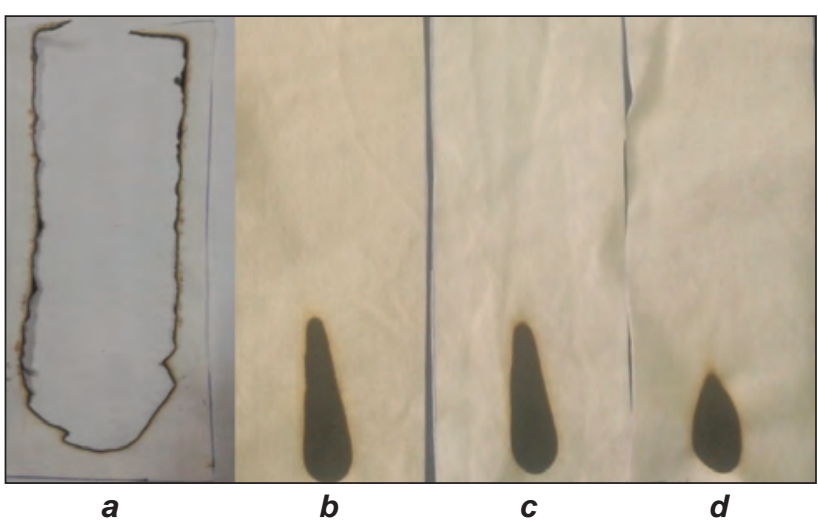

Fig. 1. $45^{\circ}$ flammability of samples: $a-$ Control; $b-\mathrm{FS} 2$ treated sample after 30 washings; $c$ - FS1 treated sample after 30 washings; $d$-FS3 treated sample after 30 washings 
LOI measurement results of fabric

The results of the LOI measurement are presented in table 6.

Table 6

THE LOI OF THE FLAME RETARDANT TREATED COTTON FABRICS WITH DIFFERENT WASHING CYCLES

\begin{tabular}{|c|c|c|c|c|}
\hline \multirow{2}{*}{$\begin{array}{c}\text { Number of } \\
\text { washing cycles }\end{array}$} & \multicolumn{4}{|c|}{ LOI of samples (\%) } \\
\cline { 3 - 5 } & Control & FS1 & FS2 & FS3 \\
\hline 0 & \multirow{4}{*}{14.9} & 33.2 & 36.3 & 26.3 \\
\cline { 1 - 3 } \cline { 4 - 5 } & & 25.0 & 27.2 & 28.5 \\
\cline { 1 - 3 } \cline { 3 - 5 } & & 25.4 & 19.3 & 25.4 \\
\hline 30 & & \multicolumn{3}{|c}{} \\
\hline
\end{tabular}

Unlike the $45^{\circ}$ burning method, the limiting oxygen index technique yielded quantitative results of flammability capacity of the fabric. The results show that the LOI values of treated samples are significantly greater than untreated samples. These differences are $18.3 \%, 21.35 \%$ and $11,4 \%$ for FS1, FS2 and FS3 treated samples, respectively. Compared to the results of table 4 and table 5 , these results could be explained as follows: the low add-on of the FS3 treated sample could be the cause of its low LOI. The LOI of the FS2 treated sample is higher than the FS1 treated sample's LOI while its add-on is smaller. This could be explained by the fact that there was the synergistic effect of phosphorus and nitrogen in the FS2 treated sample, which reduced its flammability. This difference, however, is not reflected in table 5 , which may be due to the fact that the test conditions of $45^{\circ}$ flammability test method are too low for the flameretardant capacity of these three samples.

However, after 20 and 30 laundries, the LOI values of FS3 treated samples were almost unchanged, while these values of FS1, and FS2 treated samples were reduced approximately $8-9 \%$. It was further reduced by $8 \%$ for FS2 treated samples after 30 washings cycles. These results are quite corresponding to the char lengths of samples in table 5 . Thus, the LOI values of the flame retardant treated samples using CA as crosslinking were decreased after washings. This phenomenon has also been observed in other study [8]

The results of tables $4,5,6$ show that in order to create a covalent bond between PR and cotton, the use of CA with ester linkages (Scheme 1) is more favorable than DHEU with ether linkages (case 1 of Scheme 2). However, the flame-retardant laundering durability of CA treated samples is lower than the DHEU treated sample. This phenomenon could be explained by the fact that ester bonds are more easily hydrolyzed in water than ether bonds [24]

The samples were treated by CA and CTS (FS2) have lower flame-retardant laundering durability in comparison with the other two. This suggests that the addition of CTS to the finishing solution without increasing the amount of CA may reduce the crosslink between PR and cotton because the CA could be used to create a link between CTS and cotton.
Influence of flame-retardant treatment on tensile strength of cotton fabric

First, the fabric density was tested in the treated samples, the results are presented in the table 7.

The results of table 7 show that the density of the treated fabrics stay unchanged in comparison with the control fabric. Therefore, the tensile strength of fabric samples that presented in the table 8 was used to assess the influence of flame-retardant treatment on tensile strength of cotton fabric.

\begin{tabular}{|c|c|c|}
\hline \multicolumn{3}{|c|}{ THE FABRIC DENSITY } \\
\hline \multirow{2}{*}{ Samples } & \multicolumn{2}{|c|}{ Fabric density (yarn $/ 5 \mathrm{~cm}$ ) } \\
\hline & Warp & Weft \\
\hline Control samples & 280 & 115 \\
\hline FS1 treated samples & 282 & 117 \\
\hline FS2 treated samples & 282 & 117 \\
\hline FS3 treated samples & 282 & 117 \\
\hline
\end{tabular}

Table 8

\begin{tabular}{|c|c|c|c|c|}
\hline \multirow[b]{2}{*}{ Sample } & \multicolumn{2}{|c|}{ Tensile strength $(\mathrm{N})$} & \multicolumn{2}{|c|}{ Tensile strength (N) } \\
\hline & Warp & $\begin{array}{c}\text { Change } \\
(\%)\end{array}$ & Weft & $\begin{array}{c}\text { Change } \\
(\%)\end{array}$ \\
\hline Control & 899.3 & - & 532.8 & - \\
\hline FS1 & 506.3 & -43.7 & 328.1 & -38.4 \\
\hline FS2 & 428.4 & -52.4 & 282.1 & -47.0 \\
\hline FS3 & 657.8 & -26.9 & 417.6 & -21.6 \\
\hline
\end{tabular}

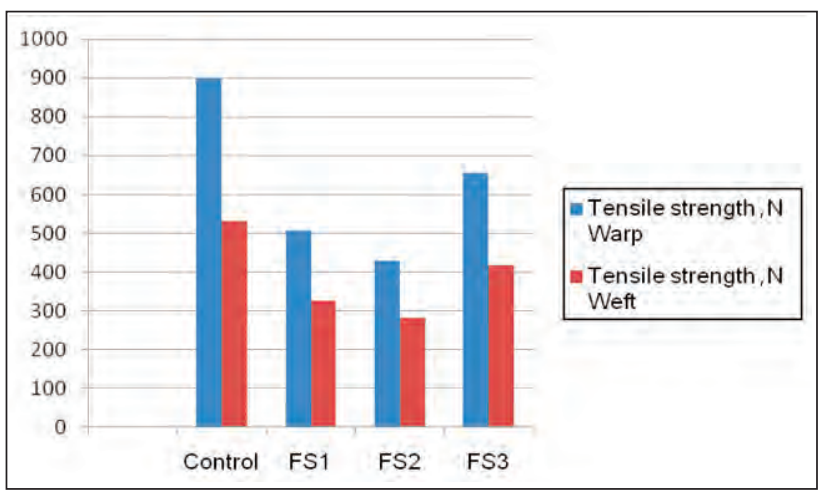

Fig. 2. Tensile strength of the control and treated samples

Table 8 and figure 2 show that, the tensile strength of the treated samples was significantly reduced compared to the untreated samples. This mechanical strength loss in the direction of warp yarn is greater than in the direction of the weft yarn. The biggest drop is for CTS and CA treated sample, then for CA treated sample and finally for the treated sample with FFRC. It could be said that the treatment in the acidic environment and curing at high temperature could be 
the cause of this mechanical strength loss. In this study, all of the three samples were treated at $180^{\circ} \mathrm{C}$ for 2 minutes, but the $\mathrm{pH}$ of finishing solution with FFRC was $6 \div 6.5$, while the $\mathrm{pH}$ of solution using $\mathrm{CA}$ and the one using CA plus CTS were only $5.3 \div 5.5$. It is possible that the difference in $\mathrm{pH}$ of the solutions leads to the difference in tensile strength of these three treated samples. The mechanical strength loss of cellulosic flame retardant treated fabrics has also been reported in several studies [10-12, 25]. However, study [10] indicates that this tensile strength loss was even observed for the cotton fabric treated only with PR without CA. Thus, the tensile strength loss is one important problem of the flameretardant treatment for cotton fabrics. PR and CA concentrations, temperature and time of curing are factors that need to be carefully selected so that the tensile strength loss is minimal.

\section{Formaldehyde content}

Results of the hydrolyzed formaldehyde amounts determined by the ISO 14184-1:1998 method are shown in table 9.

Table 9

FREE FORMALDEHYDE AMOUNT DETERMINED ACCORDING TO ISO 14184-1:1998

\begin{tabular}{|c|c|c|}
\hline Sample & $\begin{array}{c}\text { Number of washing } \\
\text { cycles }\end{array}$ & $\begin{array}{c}\text { Free formaldehyde } \\
\text { (ppm) }\end{array}$ \\
\hline FS1 & 0 & 258 \\
\hline FS2 & 0 & 246 \\
\hline FS3 & 0 & 140 \\
\hline FS1 & 1 & 103 \\
\hline FS2 & 1 & 110 \\
\hline FS3 & 1 & 122 \\
\hline
\end{tabular}

The results show that the free formaldehyde of samples treated with FS1 and FS2 is about 1.8 times higher than FS3 treated samples. This difference is corresponding to the difference in add-on values between these samples (table 4). Therefore, free formaldehyde could be derived primarily from $\mathrm{PR}$ and the difference in value of free formaldehyde may be due to the PR content of the treated sample, not due to CA. This finding confirms Drago Katovic's observation $[8,26]$ that cotton fabric which was treated only with PR without crosslinking may also have free formaldehyde more than 300 ppm.
However, in this study, the free formaldehyde content of all treated samples is less than 300 ppm, it fulfills the criterion of OEKO-TEX® standard 100 for not direct skin apparel fabrics. In addition, after only one wash, this value decreases to about 100 ppm for all three treated samples (table 9).

\section{CONCLUSION}

The results from this study show that Pyrovatex CP New provides durable flame retardancy on cotton fabric. The treated samples show good flame retardancy against the $45^{\circ}$ flammability test even after 30 wash cycles. However, the tensile strength of the treated fabrics decreased significantly, the highest reduction was $52 \%$ for fabrics treated with CA and CTS, and at least $26 \%$ for fabrics treated with Knittex FFRC. Furthermore, the treated fabrics released free formaldehyde. This free formaldehyde content is correlated to the amount of add-on of treated fabric.

The treated fabrics, using Knittex FFRC as the crosslinking, have the lowest LOI value, but the lowest loss of tensile strength and the lowest formaldehyde content. They are the best durable fire retardants. Compared to Knittex FFRC, the fabrics treated with crosslinking CA have a higher LOI value, but lower washing durability of fire resistance, higher formaldehyde content (formaldehyde content released from PR) and higher loss of tensile strength.

When adding CTS to the finishing solution using CA, the fire-retardant capacity of the treated fabric increased, but flame retardant washing durability was lower and the loss of tensile strength was also higher. Thus, Knittex FFRC and CA are both formaldehydefree finishing agents

Knittex FFRC suggests that it is a durable cross-link for fire retardant cotton fabrics using Pyrovatex CP New. It can reduce the negative impact on the mechanical strength of the treated fabric compared to the use of CA.

However, if the fire-retardant fabric is required to have a high LOI but is not required to have high fire retardant washing durability and the high mechanical strength, CA may be an effective crosslinking agent.

\section{ACKNOWLEDGMENTS}

This work was comprehended in the framework of project KC.02.13/16-20 which is financed by the MOST of Vietnam. The authors wish to sincerely thank KC.02/16-20 program, Chemical-textile LAB, Testing center of textile leather materials and Laboratory of Polymer and Composite Materials of HUST for supports during our research.

\section{REFERENCES}

[1] Jiang., et al., Enhanced flame retardancy of cotton fabrics with a novel intumescent flame-retardant finishing system, In: Fibers and Polymers, 2015, 16, 2, 388-396

[2] Visakh, P.M., Flame retardants, 2015, London, Engineering Materials

[3] Khandual, A., Green flame retardants for textiles, In: Green fashion, 2016, Springer, 171-227

[4] Magovac, E., Bischof, S., Non-halogen FR treatment of cellulosic textiles, In: Tekstil: časopis za tekstilnu tehnologiju i konfekciju, 2015, 64, 9-10, 298 
[5] Zheng, D., Zhou, J., Zhong, L., Zhang, F., Zhang, G., A novel durable and high-phosphorous-containing flame retardant for cotton fabrics, In: Cellulose, 2016, 23, 3, 2211-2220

[6] Yoshioka-Tarver, M., et al., Influence of NP Base Fiber Reactive Organophosphorus Flame Retardant on Cotton Thermal Behavior, In: AATCC Review: the magazine of the textile dyeing, printing, and finishing industry, 2012, 12, $5,52-59$

[7] Charuchinda, S.,Srikulkit, K., Mowattana, T., Co-application of sodium polyphosphate and chitosan to improve flame retardancy of cotton fabric, In: Journal of Scientific Research, Chulalongkorn University, 2005, 30, 1, 97-107

[8] Katović, D., Grgac, S.F., Bischof-Vukušić, S., Katović, A., Formaldehyde free binding system for flame retardant finishing of cotton fabrics, In: Fibres \& textiles in Eastern Europe, 2012, 1, 90, 94-98

[9] Mengal, N., Syed, U., Malik, S.A., Ali Sahito, I., Jeong, S.H., Citric acid based durable and sustainable flame retardant treatment for lyocell fabric, In: Carbohydr Polym, 2016, 153, 78-88

[10] Mohsin, M., Ahmad, S.W., Khatri, A., Zahid, B., Performance enhancement of fire retardant finish with environment friendly bio cross-linker for cotton, In: Journal of Cleaner Production, 2013, 51, 191-195

[11] Poon, C-K., Kan, C-W, Effects of TiO2 and curing temperatures on flame retardant finishing of cotton, In: Carbohydrate polymers, 2015, 121, 457-467

[12] Yasin, S., Behary, N., Giraud, S., Perwuelz, A., In situ degradation of organophosphorus flame retardant on cellulosic fabric using advanced oxidation process: A study on degradation and characterization, In: Polymer Degradation and Stability, 2016, 126, 1-8

[13] Uddin, F., Recent development in combining flame-retardant and easy-care finishing for cotton, In: Cellulose Chem. Technol, 2013, 47, 5-6, 469-477

[14] Erkan, G., Sarışık, M., Antifungal microcapsules of ethyl cellulose by solvent evaporation and their application to cotton fabric, In: Fibres \& Textiles in Eastern Europe, 2015

[15] Mohsin, M., et al., Softener impact on environment friendly low and zero formaldehyde cross-linker performance for cotton, In: De redactie, 2013, 133

[16] El-Tahlawy, K., Chitosan phosphate: A new way for production of eco-friendly flame-retardant cotton textiles, In: Journal of the Textile Institute, 2008, 99, 3, 185-191

[17] Sireerat C., Kawee S., Mowattana T., Co-application of Sodium Polyphosphate and chitosan to improve Flame Retardancy of Cotton Fabric, In: J. Sci. Res. Chula. Univ, 2005, 30, 1

[18] Stevens, C., Smith, B., Cross-linking of cotton cellulose with ethylene urea derivatives having varying hydrogenbonding capabilities: Part I: Effects on the physical properties and the hydrogen-bonded structure, In: Textile Research Journal, 1970, 40, 8, 749-760

[19] NF EN ISO 6330 - Domestic washing and drying procedures for textile testing, 2002, French

[20] ASTM D 1230 - Standard test method for flammability of apparel textiles, In: Philadelphia, PA: American Society for Testing and Materials, 1994

[21] ASTM D 2863 - Standard Test method for measuring the minimum oxygen concentration to support candle-like combustion of plastics (oxygen index), 1997

[22] BS EN ISO 13934-1:2013 Textiles - Tensile properties of fabrics - Part 1: Determination of maximum force and elongation at maximum force using the strip method (Iso 13934-1:2013), 2013

[23] NF EN ISO 14184-1 : 2011 Textiles - determination of formaldehyde - Part 1: Free and hydrolyzed formaldehyde (water extraction method), 2011

[24] Deruiter, J., Ethers and thioethers, 2005, Principles of Drug Action 1, Spring 2005, Ethers

[25] Abou-Okeil, A., El-Sawy, S., Abdel-Mohdy, F., Flame retardant cotton fabrics treated with organophosphorus polymer, In: Carbohydrate polymers, 2013, 92, 2, 2293-2298

[26] Mohsin, M., Ramzan, N., Qutab, H.G., Ahmad, S.W., Sarwar, N., Synthesis of halogen and formaldehyde free bio based fire retardant for cotton, In: Industria Textila, 2017, 68, 3, 221-225, http://doi.org/10.35530/ IT.068.03.1328

Authors:

\section{VU THI HONG KHANH ${ }^{1}$, NGUYEN THI HUONG ${ }^{1,2}$}

${ }^{1}$ Hanoi University of Science and Technology, No. 1, Dai Co Viet, Hai Ba Trung, Hanoi, Viet Nam

${ }^{2}$ Hanoi Industrial Textile Garment University, Le Chi, Gia Lam, Hanoi, Viet Nam e-mail: khanh.vuthihong@hust.edu.vn, nguyenhuonghict@gmail.com

Corresponding author:

VU THI HONG KHANH

e-mail: khanh.vuthihong@hust.edu.vn 